\title{
Characterization and development of marolo (Annona crassiflora, Mart.)
}

\author{
Edson Pablo da SILVA ${ }^{1,2 *}$, Eduardo Valerio de Barros VILAS BOAS ${ }^{1}$, Andreia Luiza Pereira Ramos XISTO ${ }^{2}$
}

\begin{abstract}
The objectives of this study was the physical, chemical, and physiological characterization of marolo (Annona crassiflora, Mart.) during its development. The fruits were harvested $12 \mathrm{Km}$ off Itumirim, Southern Minas Gerais, Brazil, at 20-d intervals from anthesis to fruit maturity. The first fruits were harvested within 60 days. The total development of the fruit took 140 days starting from anthesis. At 140 days after anthesis, the fruit reached its maximum size, with mass of $1.380 \mathrm{~g}$, transverse diameter of $13.0 \mathrm{~cm}$, and longitudinal diameter of $11.5 \mathrm{~cm}$. During its development, the fruit showed increase in mass and in traverse and longitudinal diameters. The changes during maturation and ripening, such as: $\mathrm{pH}$ reduction and starch degradation, pectic solubilization, and increase in total sugars, soluble solids $\left({ }^{\circ} \mathrm{B}\right)$, respiratory rate $\left(\mathrm{CO}_{2}\right)$, titratable acidity, vitamin $\mathrm{C}$, and $\beta$-caroteno were observed from the $120^{\text {th }}$ day of marolo development. A decrease in ability to sequester free radicals was observed up the $120^{\text {th }}$ day, followed by an increase. The volatile compounds identified at the end of the development included the esters group only.
\end{abstract}

Keywords: antioxidants; growth; maturation.

\section{Introduction}

Brazil is considered one of the most biologically diverse countries in the world, harboring about $10 \%$ of living forms on the planet. With an estimate of around 15 million species, the Brazilian biological diversity may account for 1.5 million species among vertebrates, invertebrates, plants, and microorganisms (MYERS et al., 2000).

In the "cerrado" (Brazilian savannah), there is a great diversity of fruit species with great economic and nutritional potential, but which are at risk of extinction due to human actions such as the substitution of their area of natural occurrence for pasture areas as well as coffee and sugarcane cultivation (MYERS et al., 2000). Among the fruit species of the "cerrado", the marolo tree (Annona crassiflora Mart) stands out for its strong presence in the savannah region and for its excellent sensorial characteristics, greatly appreciated by the local population.

Since fruits are living organisms, they go through a series of endogenous transformations during their development as a result of their metabolism. Fruit development is usually divided into three stages: growth, maturation, and senescence. The growth period generally involves cell division, when physical development of the fruit happens (CHITARRA; CHITARRA, 2005).

The time of harvest is determined by the maturity rate, which include physical and/or chemical characteristics confirmed by visual changes during the ripening of the fruit (PIO et al., 2005).

Ripening corresponds to changes in the sensorial characteristics such as flavor, aroma, color, and texture that make the fruit acceptable for consumption. Some of these changes are detected by the analysis of visual, physical, or endogenous transformations, for instance, changes in the levels of pigment, acid, tannin, carbohydrate, and pectin.

Although Marolo has good sensorial characteristics and great potential for commercialization, its sale is still limited to farmers' markets during harvest season, and its harvest is done through extractivism.

Therefore, the characterization of marolo during its development is of considerable importance for the development and optimization of technological methods for production, conservation, and commercialization of this fruit. The objective of the present study was the characterization of the marolo fruit (Annona crassiflora Mart) from Southern Minas Gerais, Brazil, during its development stages.

\section{Materials and methods}

\subsection{Fruit harvesting experiment setting up}

The present study was initially conducted in an area of native pasture and savannah typical for Oxisols, which is located $12 \mathrm{~km}$ off the municipality of Itumirim in Southern Minas Gerais, Brazil with altitude of 871 meters and the follwing geographical coordinates: latitude $21^{\circ} 19^{\prime} 01^{\prime \prime} \mathrm{S}$ and longitude $4452^{\prime} 16$ " W.

Thirty three (33) specimens of the species Annona crassiflora Mart were selected at random, and the flowers were marked with pieces of yarn of different colors that were tied in different parts of the plant.

The marolo fruits (harvest 2007/2008) were harvested at twenty-day intervals from its formation up to its abscission of the plant. The fruits were picked in the morning, placed in low

${ }_{1}$ Departamentos de Ciência dos Alimentos, Universidade Federal de Lavras - UFLA, CP 3037, CEP 37200-000, Lavras, MG, Brasil, e-mail: edsonpablos@hotmail.com

${ }^{2}$ Instituto Federal de Mato Grosso - IFMT, Campus Cáceres, Cáceres, MT, Brasil

${ }^{*}$ Corresponding author 
density polyethylene bags, and transported to the Postharvest Laboratory of Food Science Department at Federal University of Lavras, Brazil.

\subsection{Experimental design}

The experiment was conducted in a Completely Randomized Design (CRD) organized as a simple factorial experiment with 6 collection times $(60,80,100,120,140$, and 145 days $)$ and evaluation with four repetitions containing three fruits each.

\subsection{Physical and chemical analyses}

Mass, longitudinal, and transverse diameter (nondestructive analyses) the mass of the whole fruit was measured on a semi-analytical scale, and the results were expressed in grams (g). The longitudinal and traverse diameters of the whole fruit were measured in the two directions using a caliper, and the results were expressed in centimeters $(\mathrm{cm})$.

Color - the color was determined at five distinct points of the peel and pulp of the fruits using a Minolta CR-400 colorimeter with determinations in the CIE $L^{*} a^{*} b^{*}$ system. The $\mathrm{L}^{\star}$ coordinate represents the lightness and darkness of the sample with values varying from 0 (totally black) to 100 (totally white); the $\mathrm{a}^{*}$ coordinate can assume values from -80 to +100 , in which the extremes correspond to green and red, respectively; the $b^{*}$ coordinate, with the intensity of blue to yellow, can vary from -50 (totally blue) to +70 (totally yellow).

Respiratory activity - determined using a PBI-Dansensor $\mathrm{O}_{2} / \mathrm{CO}_{2}$ analyzer, and the results were expressed in $\mathrm{mg} \mathrm{CO}_{2} \mathrm{~kg}$ fruit $^{-1} \mathrm{~h}^{-1}$.

Firmness - was determined individually in the whole fruit with peel and in the fruit pulp, in the equatorial region using a Magness-Taylor penetrometer, with a 5/6 inch diameter probe, and the results expressed in Newtons $(\mathrm{N})$.

Soluble Solids (SS) - determined by refractometry, according to the AOAC official method (ASSOCIATION..., 1998) using a digital refractometer, and the results were expressed in ${ }^{\circ} \mathrm{B}$.

pH and Titratable Acidity (TA) - pH was determined using a Schott Handylab pHmeter, according to the AOAC official method (ASSOCIATION..., 1998). The determination of titratable acidity was conducted by titration with a sodium hydroxide solution $(\mathrm{NaOH}) 0,1 \mathrm{~N}$, using phenolphthalein as the indicator, according to the AOAC official method (ASSOCIATION..., 1998). The results were expressed in g 100 g malic acid-1.

Vitamin C - was determined by the colorimeter method with 2,4 -dinitrophenylhydrazine, according to Strohecker and Henning (1967). The reading was performed using a Beckman $640 \mathrm{~B}$ spectrophotometer with a computer, and the results were expressed in mg $100 \mathrm{~g}$ of pulp $^{-1}$.

Starch - after extraction and chemical hydrolysis, the assay was carried out using the Somogyi method, adapted by Nelson (1944), and the results were expressed in $\mathrm{g} 100 \mathrm{~g} \mathrm{pulp}^{-1}$.
Total Soluble Sugars (TSS) - were determined in a spectrophotometer at $620 \mathrm{~nm}$ by the Antrona method, and the results were expressed in $\mathrm{g} .100 \mathrm{~g}$ of pulp $^{-1}$.

Total and Soluble Pectins - extracted according to the McCready and McColomb (1952) technique and determined by spectrophotometry at $520 \mathrm{~nm}$, following the method of Blumenkrantz and Asboe-Hansen (1973). The results were expressed in mg of galacturonic acid $100 \mathrm{~g} \mathrm{pulp}^{-1}$.

Pectinmethylesterase (PME) - the enzymatic extraction was performed according to the method of Buescher and Furmanski with modifications (VILAS BOAS; CHITARRA; CHITARRA, 1996). The determination of the activity of PME was performed following the methods of Hultin, Sun and Bulger (1966) with modifications (VILAS BOAS; CHITARRA; CHITARRA, 1996). A unit of PME was defined as the amount of enzyme capable of catalyzing the demethylation of pectin corresponding to the consumption of 1 mmol of $\mathrm{NaOH} g$ pulp ${ }^{-1}$ $\min ^{-1}$.

Polygalacturonase (PG) - the extraction of the PG enzyme was performed according to the method of Buescher and Furmanski with modifications (VILAS BOAS; CHITARRA; CHITARRA, 1996). Enzymatic activity was expressed in $\eta \mathrm{mol}$ of galacturonic acid g pulp ${ }^{-1} \mathrm{~min}^{-1}$.

Determination of antioxidant activity - it was based on the extinction of the 2,2-diphenyl-1-picryl-hydrazyl (DPPH $60 \mu \mathrm{M})$ radical absorption, according to Rufino et al. (2007) with some adaptations in terms of calculation (calculated in grams of DPPH/gram of fruit), according to the straight line equation obtained from the standard curve with the DPPH concentrations that varied from 0 to $60(\mu \mathrm{M})$, the percentage of the DPPH radical sequestration was determined based on the control DPPH.

Determination of phenolic compounds - the quantification of the compounds with reducing capacity, among which are the phenolic compounds present in the pulp fractions, was performed by spectrophotometry $(760 \mathrm{~nm})$ using the FolinDennis colorimetric method mixture of phosphomolybdate and phosphotungstate (Folin-Denis reagent). Reduction was performed in alkaline solution by the benzenoid poly hydroxylate compounds forming molybdenum blue that will be more intense with the presence of higher number of hydroxyls.

Determination of $\beta$ carotene - extracted with acetonehexane (4:6) and determined according to Nagata and Yamashita (1992); the results were expressed in mg $100 \mathrm{~g}^{-1}$. Absorbance was read using a spectrophotometer at $A_{663}, A_{645}, A_{505}, A_{453}$, and content was determined using the following equation: $\beta$ carotene $=0.216 \mathrm{~A}_{663}-1.22 \mathrm{~A}_{645}-0.304 \mathrm{~A}_{505}+0.452 \mathrm{~A}_{453}$.

Volatile compounds - The volatile compounds were extracted by the solid phase microextraction (SPME) technique. One gram of pulp was transferred to a $10 \mathrm{ml}$ glass flask (appropriate for volatile retention) agitated, and heated at $70{ }^{\circ} \mathrm{C}$ for 15 minutes. $75 \mu \mathrm{m}$ carboxen/ polydimethylsiloxane fiber (CAR/PDMS) were used to screen the volatile compounds present in the sample. The $75 \mu \mathrm{m}$ fiber (CAR/PDMS) was stored at $300{ }^{\circ} \mathrm{C}$ for 1 hour before utilization. The time between the 
storage of the analytes before exposure to the fiber was 25 minutes. The fiber was exposed to the headspace of the glass flask $(10 \mathrm{~mL})$, containing 1 gram of the marolo sample. After 15 minutes of exposure to the fiber at a temperature of $70^{\circ} \mathrm{C}$, the syringe was immediately placed into the GC MS injector, in which the volatile compounds were desorbed at $250{ }^{\circ} \mathrm{C}$ in splitless mode for 2 minutes (those with development time of $60,80,100$, and 120 days) and at $250{ }^{\circ} \mathrm{C}$ for 1 minute (those with development time of of 140 and 145 days).

The identification of the volatile compounds was carried out at the Chemical Analysis Laboratory, Federal University of Lavras, Brazil. A Shimadzu CG-17A equipment with a selective mass detector (model QP5050A) was used under the following operational conditions: fused silica capillary column of 30 $\mathrm{m} \times 0.25 \mathrm{~mm}$ ID and $0.25 \mu \mathrm{m}$ film thickness and stationary phase 5\% diphenyl/ 95\% polydimethylsiloxane (DB5); injector temperature $270^{\circ} \mathrm{C}$; initial column temperature $60^{\circ} \mathrm{C}$, thermal ramp of $3^{\circ} \mathrm{C}$ per minute to $270^{\circ} \mathrm{C}$; helium carrier gas, with 1.8 $\mathrm{mL} \cdot \mathrm{min}^{-1}$ flow rate in the column; without the splitless mode and with initial column pressure of $100 \mathrm{KPa}$.

The mass spectrometry (MS) operating conditions were as follows: selective mass detector operating in electronic impact mode, and energy of impact of $70 \mathrm{eV}$; scan speed $1000 \mathrm{~m} / \mathrm{z} \mathrm{s}^{-1}$; scan interval of 0.5 fragments/second, and fragment detection of $29 \mathrm{Da}$ and $600 \mathrm{Da}$. Each component was identified by comparing its mass spectrum with those available in the literature (ADAMS, 1995) and a database (Wiley 7).

Statistical Analysis - The statistical analysis of the physical and chemical variables was performed using the software SISVAR (FERREIRA, 2000). After the analysis of variance of the results obtained, the level of significance was verified using the F test. The means of the period of time evaluated (weeks) were submitted to polynomial regression, in which the models were selected according to the significance of the test $F$ of each model and to the coefficient of determination.

\section{Results and discussion}

The flowering of the marolo tree in Itumirim, Southern Minas Gerais, Brazil, began between the end of September and beginning of October 2007. Fructification was initially observed at the end of October with peak production at the end of February and beginning of March of 2008.

The total development of the fruit took 140 days; from flower opening (anthesis) up to fruit abscission. The fruits were harvested at 140 days of development and stored at $20^{\circ} \mathrm{C}$; their softening and characteristic aroma were monitored. On the fifth day of storage, the fruits showed an improvement in the peculiar characteristics that are desirable for consumption; this period of time was then established as 145 days.

The period of time between anthesis and ripening varies in different species of fruits (MARTINS et al., 2003; MOURA et al., 2004). The development stage of fruits begins, usually, with fertilization, which is followed by stages such as formation, growth and maturation, including the ripening phase and senescence (TAIZ; ZEIGER, 2002).
A significant increase in the mass and transverse and longitudinal diameters of the marolo fruit was observed, characterizing the growth of the fruit from its formation to its ripening $(\mathrm{p}<0.05)$ (Figure 1$)$. Based on the statistical analysis, the marolo fruit mass increased linearly during its development, with mean values varying from $377.56 \mathrm{~g}$ to $1,452.97 \mathrm{~g}$, at 60 , and 140 days after anthesis; however, at 145 days, the fruit had already been harvested, and the average mass content 1,395.03 g. Quadratic behavior increase was observed for the variables transverse and longitudinal diameter.

During the vegetative growth, there is an irreversible increase in size, which enables its evaluation through the three variables studied in this experiment.

The highest growth rate was verified between the 60th and 80th days of development $\left(1.25 \mathrm{~mm} \cdot \mathrm{dia}^{-1} 0.8 \mathrm{~mm} \cdot \mathrm{dia}^{-1}\right.$ and 24.64 g.dia ${ }^{-1}$, for transverse and longitudinal diameters and mass, respectively). Between the 80th and 100th day, significant changes were observed with a reduction in the growth rate $\left(0,2 \mathrm{~mm} \mathrm{dia}^{-1}, 0.13 \mathrm{~mm} \mathrm{dia}{ }^{-1}\right.$ and $\left.11.38 \mathrm{~g} \mathrm{dia}^{-1}\right)$ followed by an increase up to the 120 th $\left(0.4 \mathrm{~mm} \mathrm{dia}^{-1}, 0.6 \mathrm{~mm} \mathrm{dia}^{-1}\right.$ and $\left.23.95 \mathrm{~g} \mathrm{dia}^{-1}\right)$ and another reduction up the 140 th day $(0.3 \mathrm{~mm}$ $\mathrm{dia}^{-1}, 0.3 \mathrm{~mm} \mathrm{dia}{ }^{-1}$ and $7.61 \mathrm{~g} \mathrm{dia}^{-1}$ ), which suggests a double sigmoidal growth pattern. In general, fruit growth assumes a simple sigmoidal pattern, as in the case of apple, banana and orange, or double as in peach, cherry, and grape (CHITARRA; CHITARRA, 2005).

The $L^{*}, a^{*}$ and $b^{*}$ parameters of the peel and pulp of the marolo were significantly influenced by the development of the fruit. However, the polinomial adjustment of the observed data was only possible for the value $\mathrm{a}^{\star}$ of the peel and the value $b^{*}$ of the marolo pulp $(p<0.05)$. The peel value $a^{\star}$ of the fruits increased linearly during its development, varying from -5.0 to +3.5 , from the 60 th to the 145 th day, characterizing loss of green color during the development (Figure 1). The green color is due to the presence of chlorophyll, and the tendency towards loss is associated with its degradation. Several factors can affect fruit degradation separately or together; among them are $\mathrm{pH}$, influenced by the organic acids present in the vacuoles, the oxidative systems, and the chlorophyllase (TAIZ; ZEIGER, 2002).

The most noticeable change observed during the development of the marolo is associated with its pulp pigmentation evidenced by an increase in the $b^{\star}$ value (cubic behavior), especially starting from the 120th day (Figure 1), indicating the yellow color development in the pulp. The carotenoids are the pigments responsible for the yellow color in the peel and pulp of fruit. The increase observed in the concentration of $\beta$-carotene (Figure $2 \mathrm{~b}$ ) was significant, especially starting from the 120th day of development. The values of $L^{*}, a^{*}$ and $b^{*}$, varied from 35.81 to $42.36 ;-4.77$ to 3.23 , and 15.81 to 10.05 in the peel, respectively, and from 84.74 to $74.21 ;-0.5$ to 3.71 , and 26.41 to 39.30 in the pulp, indicating a variation in the peel color from green to brown, and in the pulp from light yellow to orange. Basulto et al. (2009), reported the major changes in the quality attributes of papaya that occur during the ripening process in order to identify maturity stages 

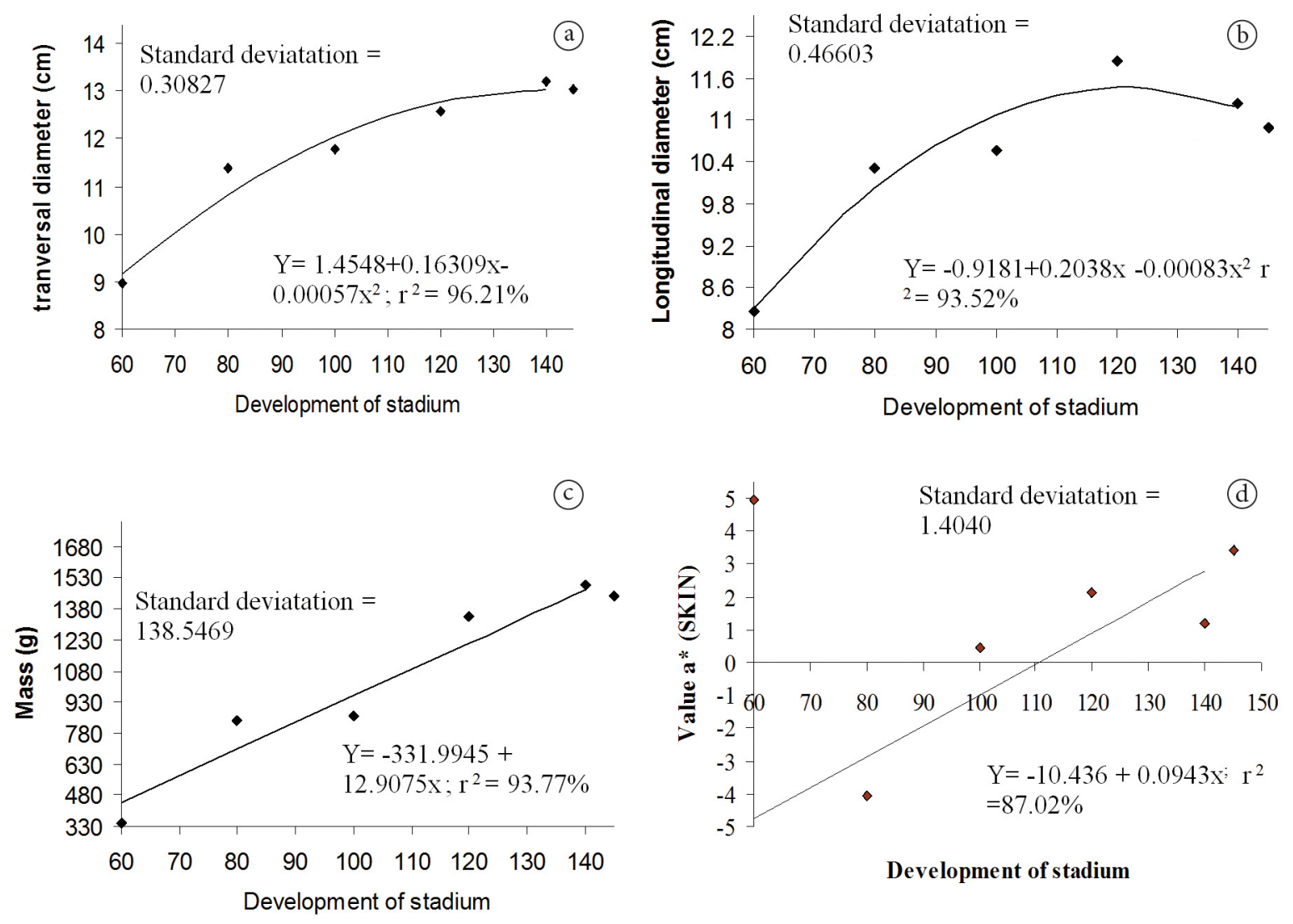

Development of stadium

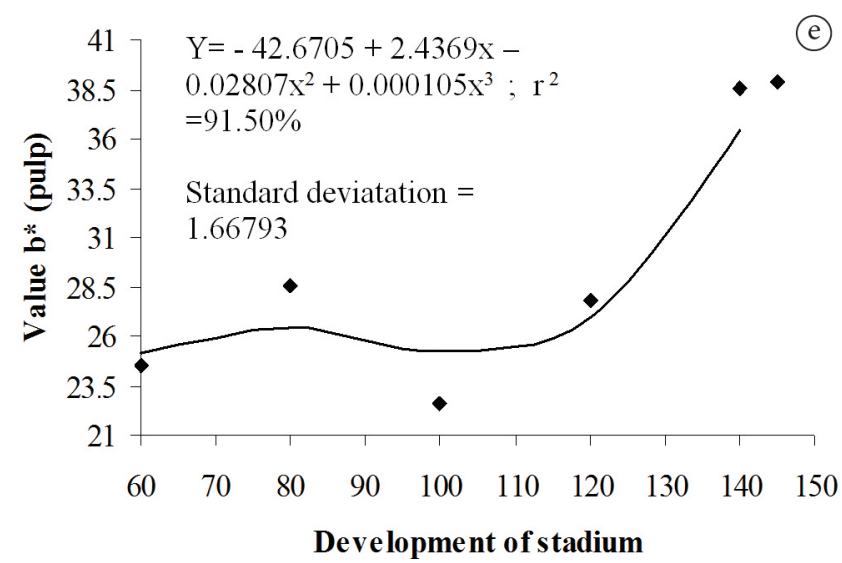

Figure 1. Average adjusted values and regression equations of the transverse (a); longitudinal (b) diameters and mass (c); (d) equations of the $\mathrm{a}^{*}$ coordinate in the peel; (e) equations of the $\mathrm{b}^{*}$ coordinate in the pulp during the development of the marolo (Annona crassiflora Mart).

and define objective maturity indices to be used as harvest indices and quality standards.

The changes in the color during fruit maturation are due to degradative processes or synthetic processes, in which the carotenoid pigments can be synthesized or unmasked simultaneously with the degradation of other substances (FISCHER; BENNET, 1991).

In this study, a significant increase was observed in the respiratory metabolism, reflected by the accumulation of $\mathrm{CO}_{2}$, (quadratic behavior), especially from the 100th day up to the 140th day of development, without the presence of a respiratory peak during the stages (Figure 3a). At 145 days of development, the accumulation of $\mathrm{CO}_{2}$ in the fruits was lower than that of the fruits at 140 days due to the advanced maturity stage of the fruits at this point.

The respiratory process corresponds to oxidation reactions of organic compounds (organic acids and carbohydrates), which are transformed into water and carbon dioxide with the production of chemical energy used for the biosynthesis of new compounds that are indispensable for perfect cellular operation (CHITARRA; CHITARRA, 2005). 

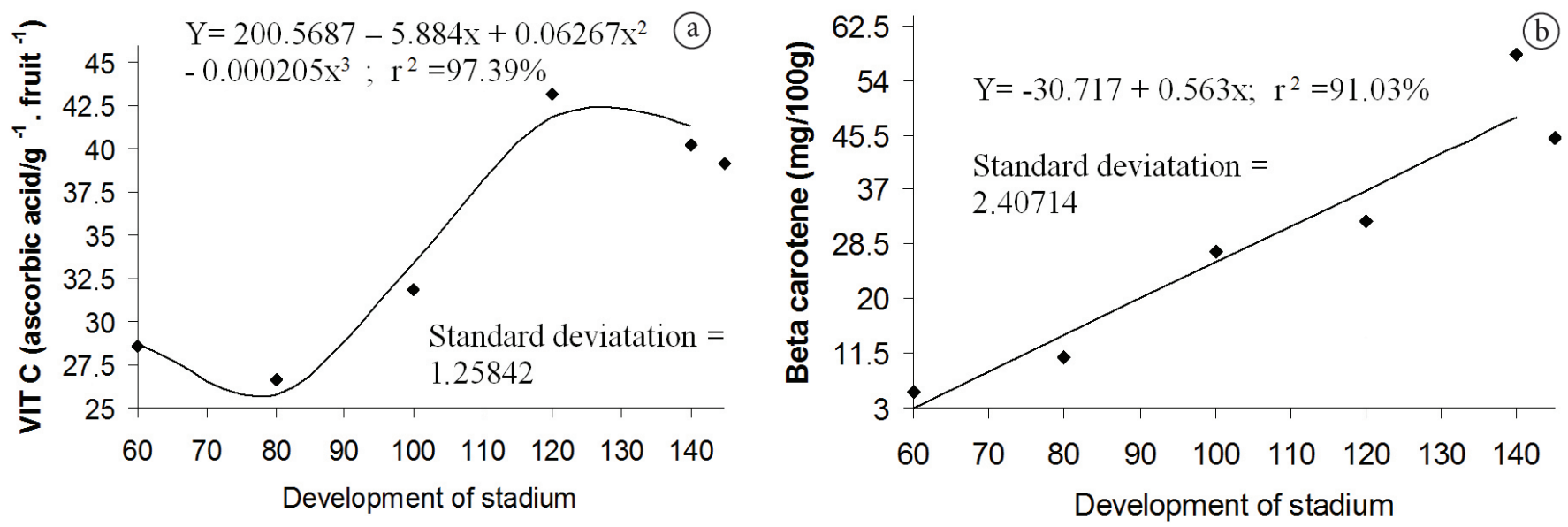

Figure 2. Average adjusted values and regression equations for the variables vitamin $\mathrm{C}$ (a); $\beta$-carotene (b) in the development of the marolo (Annona crassiflora Mart).

It was observed that there was decrease in the $\mathrm{pH}$ value and an increase in the acidic levels during the development of the marolo fruit; malic acid was the predominant acid especially, which increased from the 120th and 100th days of development of the fruits, (Figure 3a).

The most significant respiratory activity increase (Figure 3b, c) coincided with the increase in acidity of the marolo fruit. This increase is related to the increase in its synthesis during the Krebs cycle which is related to the respiratory process of the fruit.

As the climacteric fruits approach maturity, there is a characteristic increase in the respiration rate, hormones and ethylene precursor synthesis, cell wall degradation, and sugar synthesis resulting from the degradation of fruit energy. At that stage, the organic acids are used as an energy source speeding up the fruit maturity stage; the $\mathrm{pH}$ decreases due to its consumption as substratum in the respiratory process or its conversion to sugars and, consequently, acidity increases (GARDIAZABAL; CANO, 1999).

The levels of total soluble sugars and soluble solids varied between 3 and 5\%, respectively, up to the 120th day of development, while an increase was observed in the starch levels (Figure $4 \mathrm{a}, \mathrm{b}$ ). The levels of total soluble sugars and soluble solids in the marolo fruit increased from the 120th day of development, when increased starch levels and the beginning of their degradation process or conversion into sugar were observed (Figure 4c), indicating the onset of its degradation characterized by its conversion to sugars, which suggests the beginning of ripening. This period of intense carbohydrate metabolism, also coincided with the period of highest increase in the respiration rate of the marolo fruit (Figure 3).

Starch degradation in the final development stages can be related to an increase in the respiratory process, serving as energy source for the maintenance of the physiological process. Its conversion into glucose in the fruits determined the color and sweetening of the pulp, which can be associated to the development of the edibleness of the fruit; these sugars can be derived directly from the sap before or together with the degradation of starch.

The soluble solids are mostly made up of sugars. The level of soluble solids depends on the maturity stage at which the fruit is picked, and usually it increases during maturation by the biosynthesis of mono and disaccharides or degradation of polysaccharides (TAIZ; ZEIGER, 2002).

An increase in the total pectin levels was observed, at the 120th day of development, followed by a decrease between the 140th and 145th days. As for the soluble pectin, a tendency toward increase was observed during the whole fruit development (Figure 5a, b). In general, during maturation and ripening, a reduction in the total pectin level with the increase in the degree of solubilization contributing to the softening of the tissues has been observed (FISCHER; BENNET, 1991).

The activity of the cell wall enzymes, pectinmethylesterase (PME) and polygalacturonase (PG), was not observed in the fruits up to the 140th and 120th day of development, respectively. Low enzymatic activities of PG were observed at the 140th and 145th days of development, and high activity of PME was observed at 145 days (Table 1). The enzymatic activities at the end of the fruit development can be associated, partially, to pectic solubilization; however, enzymatic activity alone cannot explain this fact (Figure 6b). The increase in the pectic solubilization during fruit development suggests the activity of other enzymes related to cell wall degradation.

The variables firmness of the unpeeled fruit and pulp were affected by the development of the marolo fruit. According of Rodríguez-Félix, Fortiz Hernández and Villegas Ochoa (2011), firmness is one of the main indicators of maturity and a predictor of shelf life. There was an increase in the firmness values of the unpeeled fruits up to the 120th day, followed by a decrease. As for the pulp, the first decrease was observed between the 60th and the 80th day, followed by stabilization up to the 120th, with a subsequent decrease (Figure 7), indicating fruit softening. The decrease in firmness, especially from the 120th day, can be associated to the degradation of starch and pectic solubilization. 

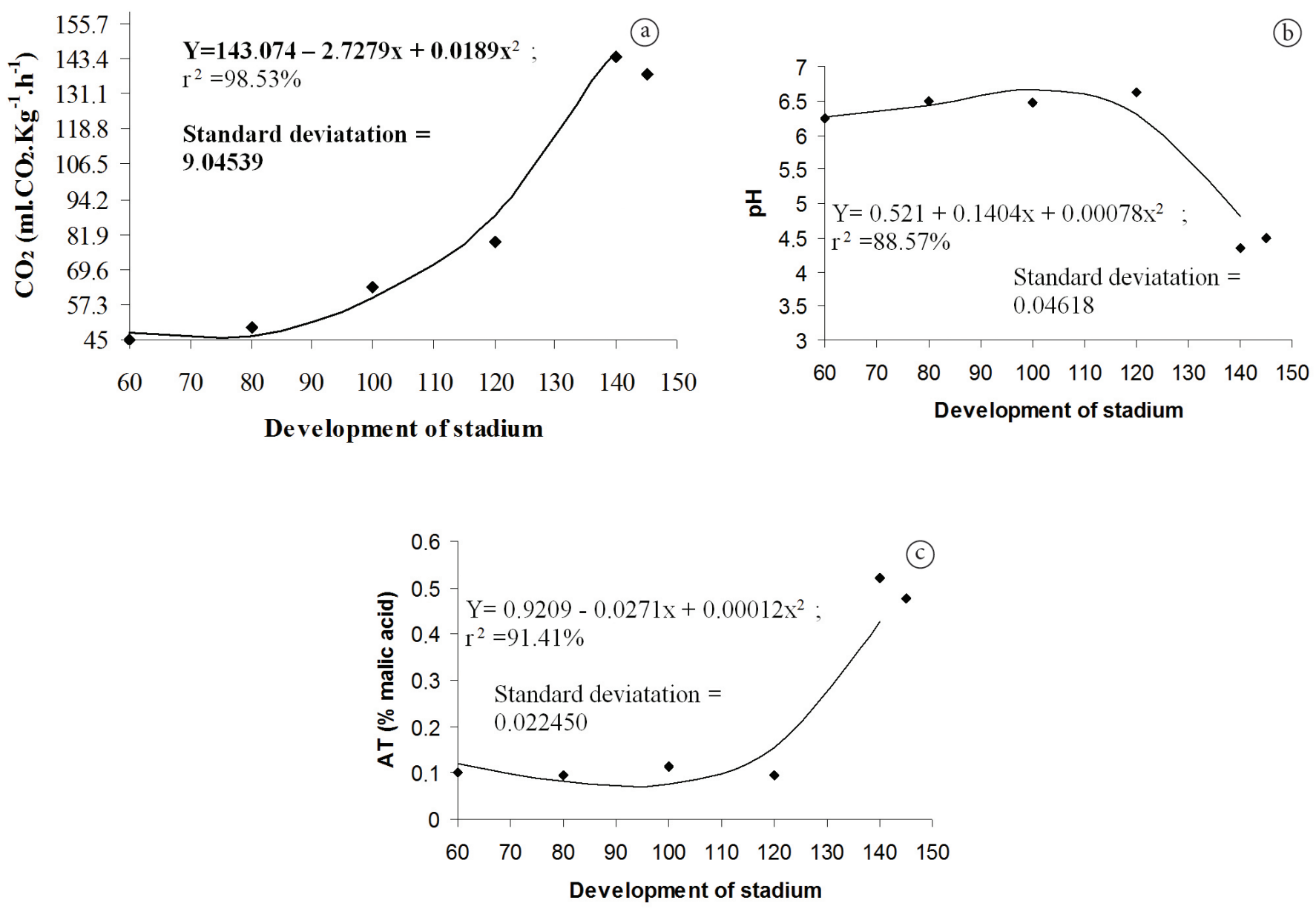

Figure 3. Average adjusted values and regression, (a) equations for the respiratory atividade; (b) equations for the variables pH; (c) and titratable acidity during the development of the marolo (Annona crassiflora Mart).

Table 1. PME and PG enzymatic activity during the development of the marolo.

\begin{tabular}{ccc}
\hline $\begin{array}{c}\text { Development } \\
\text { stage }\end{array}$ & $\begin{array}{c}\text { PME Activity } \\
\left(\eta \mathrm{mol} \mathrm{g}^{-1} \mathrm{~min}^{-1}\right)\end{array}$ & $\begin{array}{c}\text { PG Activity } \\
\left(\eta \mathrm{mol} \mathrm{g}^{-1} \mathrm{~min}^{-1}\right)\end{array}$ \\
\hline 140 days & - & 37.215 \\
145 days & 3166.732 & 6.110 \\
\hline
\end{tabular}

Softening is a notable characteristic observed during the ripening of fruits. Ripening is the fruit development stage in which they are ready for consumption. As the fruit ripens, it tends to soften due to the depolymerization and solubilization of cell wall compounds, notably the pectins. This process is mediated by enzymes such as pectinmethylesterase (PME), polygalacturonase (PG) and betagalactosidase (VILAS BOAS; KADER, 2006). Although the enzymes PME and PG might have had some influence in the softening from the 140th day, the activity of other cell wall enzymes in the softening process is suggested.

The pectin methyl esterase esterifies polyuronides by removing methyl groups from the $\mathrm{C} 6$ position of galacturonic acid residues of high molecular weight pectin. The demethylation of the pectin and its carboxyl groups leads to $\mathrm{pH}$ changes in the cell wall allowing for the aggregation of polyuronides into a Ca-linked gel structure, making the polyuronides susceptible to degradation by PG (BRUMMELL; HARPSTER, 2001).

The levels of vitamin $C$ and beta carotene were significantly affected by the development of the fruit confirmed by their increased levels during fruit development $(p<0.05)$. The maximum value of vitamin $C$ was observed at the 120th day of development, followed by a decrease (Figure 2a). The most significant vitamin $\mathrm{C}$ level detected was higher than those found by Almeida (1998) in ripe marolo fruit and lower than the results found by Rodrigues et al. (2009) and Silva et al (2009), who studied the development of the peki and gabiroba fruits, native to the savannah.

Increases in the levels of $\beta$-carotene were observed up to 140 days, followed by a decrease at 145 days (Figure 2b). This decrease can be related to the degradation of the carotenoids, contributing to the synthesis of volatile compounds characteristic of the species.

At the end of the development, marolo showed significant levels of vitamin $C$ and beta carotene, substances that have great benefits to public health because they can act as powerful antioxidants fighting free radicals. The substances with health promotion potential present in foods are polyphenols 

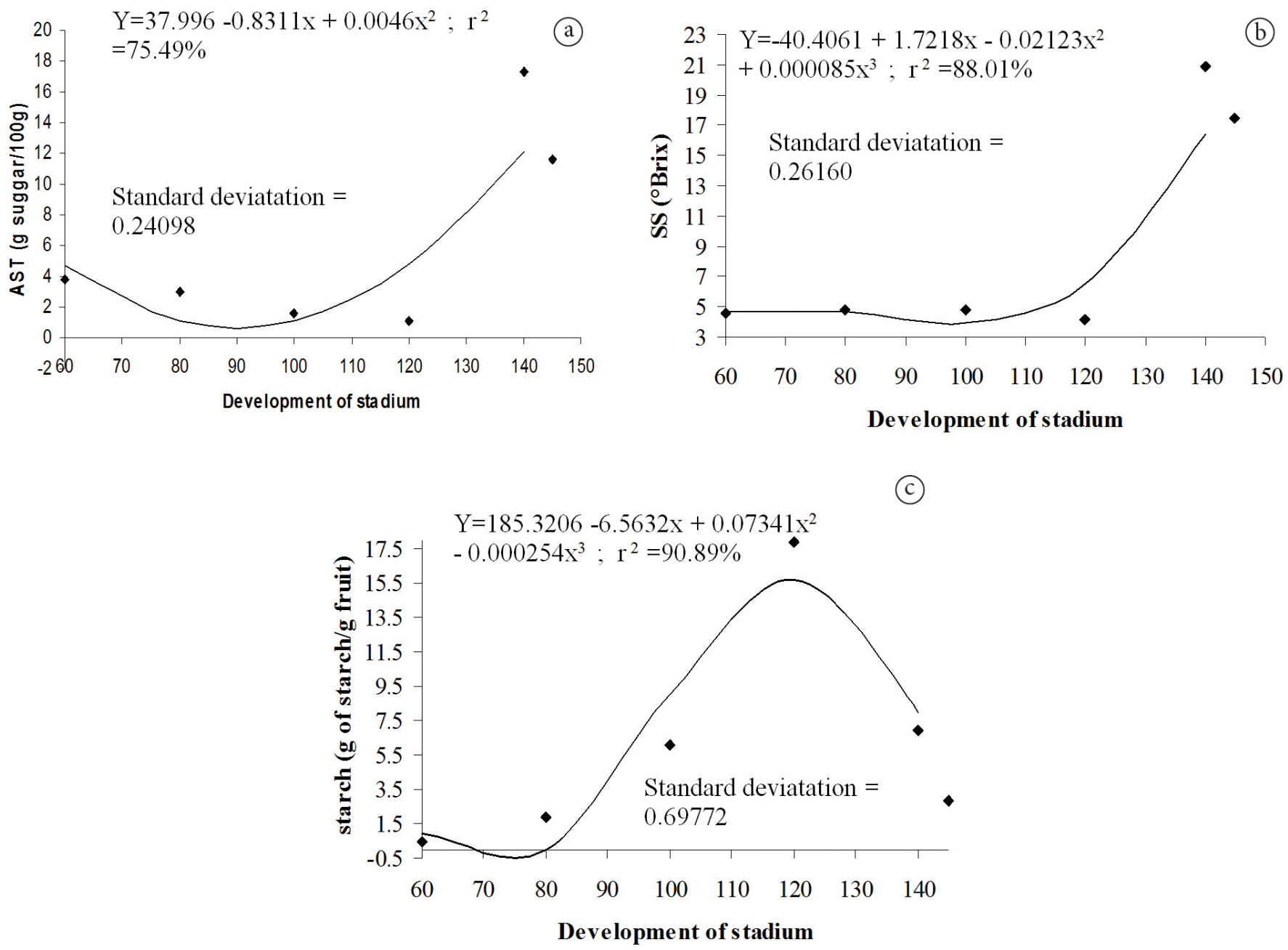

Figure 4. Average adjusted values and regression equations found for the variables total sugars (a), soluble solids (b) and starch (c) during the development of the marolo (Annona crassiflora Mart).

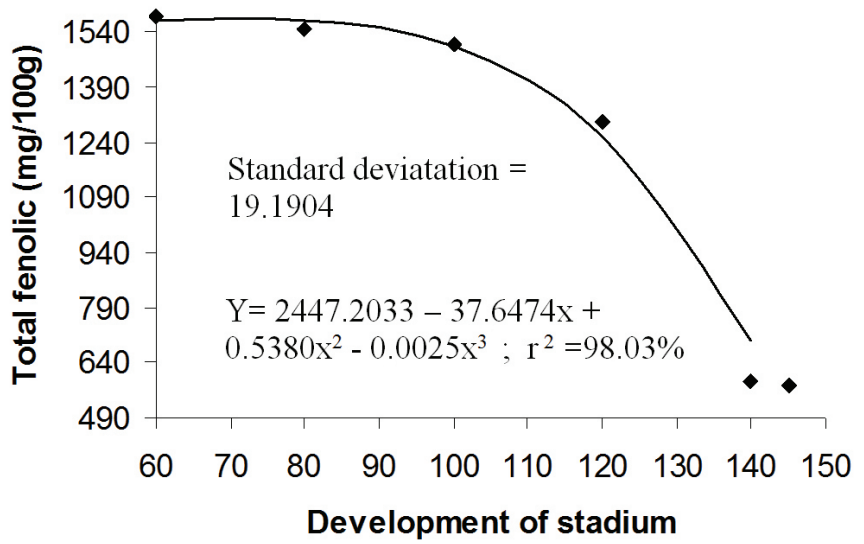

Figure 5. Average adjusted values and regression equations for the variable phenolic compounds during the development of the marolo (Annona crassiflora Mart).

(flavonoids and isoflavones), the oligosaccharides (such as the fructooligosaccharides), carotenoids, and ascorbic acid (CANNIATTI-BRAZACA, 2007). The recommended daily intake of nutrients such as vitamin $C$ and $\beta$-carotene (vitamin
A) is 60 to $100 \mathrm{mg} /$ day and 660 to $915 \mu \mathrm{g} /$ day, respectively. The consumption of 250 grams of marolo, one fourth of the fruit, satisfies these nutritional requirements (BRASIL, 1998).

During the fruit development, a considerable percentage of the DPPH (2,2-Diphenyl-1-picryl-hidrazil) radical sequestration of the fruits (Figure 8) was observed. The higher this percentage, the higher the antioxidant capacity of the vegetable. This high percentage of DPPH radical sequestration can be associated with the high phenolic levels (Figure 5), which in turn are associated with the synthesis of ascorbic acid and beta-carotene (Figures 2a, b) during the fruit development. At the 120th day of development, there was a decrease in the DPPH sequestration percentage, which can be attributed to the decrease in the phenolic compounds (Figure 5), powerful antioxidants. The increase, starting from the 120th day, can be associated to the synthesis of $\beta$-carotene (Figure $2 \mathrm{~b}$ ). Roesler et al. (2007) reported that the phenolic compounds have better correlation with DPPH radical sequestration than that of vitamin $C$, in other words, phenolic compounds have better activity. This behavior was also observed in this study because the decrease in the antioxidant capacity (Figure 8) coincided with the decrease in the phenolic compounds (Figure 5). According to the same author, other 

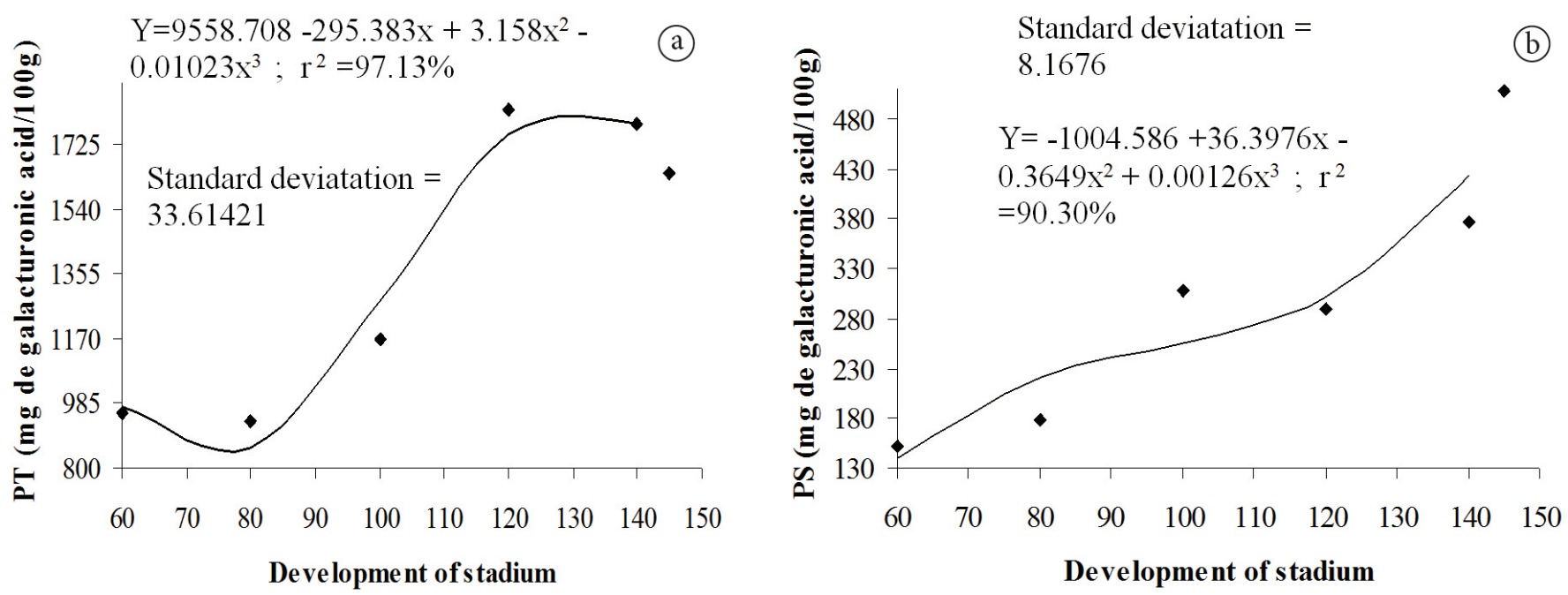

Figure 6. Average adjusted values and regression equations of the variables total pectin (a) and soluble (b) during the development of the marolo (Annona crassiflora Mart).
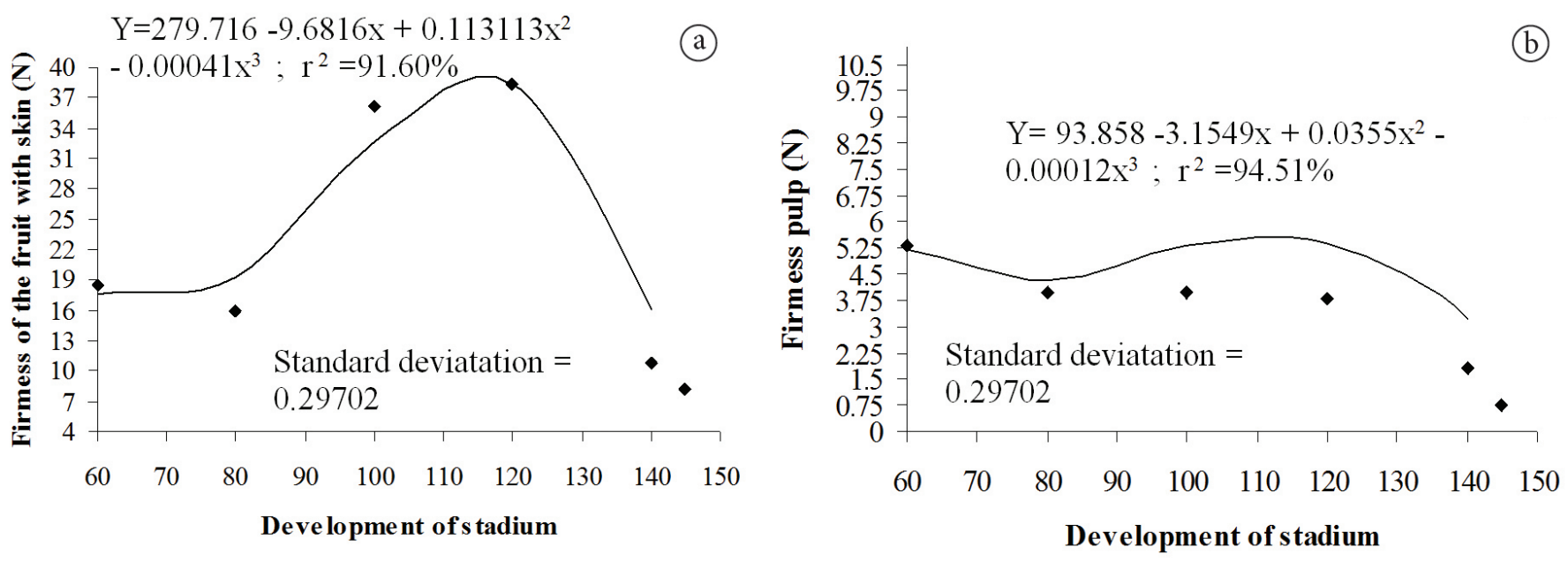

Figure 7. Average adjusted values and regression equations of the variable firmness for unpeeled fruit and the pulp during the development of the marolo (Annona crassiflora Mart).

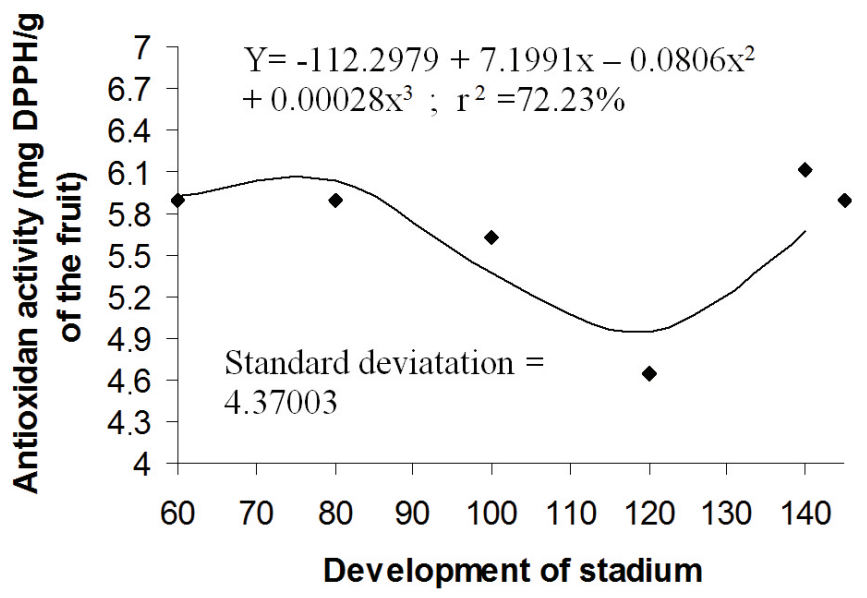

Figure 8. Average adjusted values for the variable sequestration $\%$ of the DPPH radical in the development of the marolo (Annona crassiflora Mart). studies indicate that this correlation between the phenolics and the antioxidant capacity may depend on the method chosen and on their hydrophobic or hydrophilic characteristics.

Melo et al. (2008), studying the antioxidant capacity of fruits, observed a DPPH (2,2-Diphenyl-1-picryl-hidrazil) sequestration percentage higher than $70 \%$ for acerola, sugar apple, cashew apple, and guava acetonic extracts, which were higher than $60 \%$ of the synthetic antioxidant BHT. The results observed in the marolo fruit, were higher than the values found by this author demonstrating the high potential of the marolo to DPPH sequestration.

In addition to the antioxidant capacity, phenolics can influence the flavor determining fruit astringency and bitterness. During ripening, the astringency level decreased in response to the decrease in soluble tannins in water, giving a pleasant flavor to the fruit. This is due to the polymerization of the existent tannins that originate larger molecules, which are insoluble in 
water and do not have the ability to react with the taste buds of the mouth (VILAS BOAS; KADER, 2006).

The volatile compounds are of great importance for the development and maintenance of fruits because they are involved with seed dispersion and the dissemination process for species maintenance; they can also directly influence consumer acceptance. At 60 days after the anthesis, the following compounds were identified: $\beta$ pinene (monoterpene), ethyl hexanoate, beta-linalool, methyl and ethyl octanoate, and bicyclogermacrene. According to Silva et al. (2007), bicyclogermacrene is a sesquiterpenoid compound that can have antifugal activity. At the 80th day, the profile of the volatile compounds was similar to that observed at 60 days; however, ethyl hexanoate was not detected.

For the fruits with 100 days of development, the emergence of two new compounds was detected: methyl-hexanoate and nonanal; nonanal was only identified at this stage. The 100th day was the last time bicyclogermacrene was detected, which indicates that with the development of the fruit, this compound stopped being synthesized.

At 120 days after anthesis, beta-caryophyllene was the new compound identified; however, it was not detected in the fruits at the 140th and 145th days. The beta caryophyllene compound is a terpenoid compound present in the copaiba oil with proven anti inflammatory and pharmacological action (SILVA et al., 2007).

In the fruits with 140 and 145 days of development, all compounds detected belong to the esters' chemical class, which is the major class of fruit volatiles.

Although carotenoid degradation took place between the last stages of the marolo fruit development, apparently, it did not contribute to the synthesis of volatiles because the presence of terpenoid compounds was not detected at the 140th and 145 th days of development. The majority of compounds found were: methyl and ethyl octanoate, methyl and ethyl hexanoate, and methyl and ethyl decanoate demonstrating the possible importance of these compounds for the aroma of the marolo. Damiani et al. (2009) obtained similar results studying the volatile compounds of the peki fruit, another fruit native to the Brazilian savannah. The volatile compounds that form the characteristic flavor of fruits are produced through metabolic routes during maturation, harvest, postharvest, and storage, and they depend on many factors such as species, variety, and the type of technological treatment used (RIZZOLO; POLESELLO; POLESELLO, 1992).

The most important compounds responsible for aroma include mono and sesquiterpenes, phenolic derivatives, lipid derivative compounds, amino acid derivative compounds, and compounds derivative of the carotenoid breakdown, among others, (LEWINSOHN et al., 2005).

\section{Conclusion}

According to the results obtained, it can be concluded that:

The full development of marolo took 140 days, and the fruits increased mass and size during development. After 120 days of development, there was an increase in respiratory rate, conversion of starch into sugar, pulp softening associated with pectin solubilization, $\mathrm{pH}$ reduction, and an increase in levels of acidity and soluble solids. The volatile profile changed during the fruit development.

The marolo fruit is a considerable a good source of vitamins (A and C), fiber, and antioxidant compounds.

\section{Acknowledgments}

The authors are grateful for the financial support provided by CAPES, CNPq and FAPEMIG.

\section{References}

ADAMS, R. P. Identification of essential oil components by gás chromatography/mass spectroscopy. Carol Stream: Allured, 1995. $469 \mathrm{p}$.

ALMEIDA, S. P. Frutas nativas do cerrado: caracterização físicoquímica e fonte potencial de nutrientes. In: ALMEIDA, S. P. Cerrado: ambiente e flora. Planaltina: Embrapa-CPAC, 1998. p. $247-281$

ASSOCIATION OF OFFICIAL AGRICULTURAL CHEMISTS - AOAC. Official methods of the Association of the Agricultural Chemists. Washington: Association of Official Agricultural Chemists, 1998. $1094 \mathrm{p}$.

BASULTO, F. S et al. Maduración postcosecha e índices de madurez de papaya maradol. INCI, v. 34, n. 8, p. 583-588, 2009.

BLUMENKRANTZ, N.; ASBOE-HANSEN, G. New method for quantitative determination of uronic acids. Analytical Biochemistry, v. 54, p. 484-489, 1973. http://dx.doi.org/10.1016/00032697(73)90377-1

BRASIL. Agencia Nacional de Vigilancia Sanitaria. Portaria n 27 de 13 de Janeiro de 1998. Regulamento técnico sobre a informação nutricional complementar. 1998. Disponível em: <http://www. anvisa.gov.br>. Acesso em: 10 Apr. 2012.

BRUMMELL, D. A.; HARPSTER, M. H. Cell wall metabolism in fruit softening and quality and its manipulation in transgenicplants. Plant Molecular Biology, v. 47, p. 311-340, 2001. PMid:11554479. http://dx.doi.org/10.1023/A:1010656104304

CANNIATTI-BRAZACA, S. G. Pós-colheita de frutas e hortaliças. Visão Agrícola, Piracicaba, v. 4, n. 7, p. 15-17, 2007.

CHITARRA, M. I. F.; CHITARRA, A. B. Pós-colheita de frutos e hortaliças: fisiologia e manuseio. 2. ed. Lavras: FAEPE, 2005. 785 p.

DAMIANI, C. et al. Volatile compounds profile of fresh-cut peki fruit stored under different temperatures. Ciência e Tecnologia de Alimentos, v. 29, p. 435-439, 2009. http://dx.doi.org/10.1590/ S0101-20612009000200032

FERREIRA, D. F. Análises estatísticas por meio do SISVAR para Windows versão 4.0. In: REUNIÃO ANUAL DA REGIÃO BRASILEIRA DA SOCIEDADE INTERNACIONAL DE BIOMETRIA, 45., 2000, São Carlos. Resumos... São Carlos: UFSCar, 2000. p. 235.

FISCHER, R. L.; BENNET, A. B. Role of Cell wall hydrolases in fruit ripening. Annual Review of Plant Physiology and Plant Molecular Biology, v. 42, p. 675-703, 1991. http://dx.doi.org/10.1146/annurev. pp.42.060191.003331

GARDIAZABAL, F.; CANO, G. Caracterización de 10 cultivares de chirimoya (Annona cherimola Mill.) y su respuesta a la polinización 
artificial en Quillota, Chile. Acta horticulturae, v. 497, p. 239-253, 1999.

HULTIN, H. O.; SUN, B.; BULGER, J. Pectin methyl esterase of the banana: purification and properties. Journal of Food Science, Chicago, v. 31, n. 3, p. 320-327, 1966. http://dx.doi. org/10.1111/j.1365-2621.1966.tb00500.x

LEWINSOHN, E. et al. Carotenoide pigmentation affects the volatile composition of tomato and watermelon fruits, as revealed by comparative genetic analyses. Journal of Agricultural and Food Chemistry, v. 53, p. 3142-3148, 2005. PMid:15826071. http://dx.doi. org/10.1021/jf047927t

MARTINS, L. P. et al. Desenvolvimentos de ciriguela (Spondias purpúrea). Revista Brasileira de fruticultura, v. 25, n. 1, p. 11-14, 2003. http://dx.doi.org/10.1590/S0100-29452003000100005

McCREADY, P. M.; McCOLOMB, E. A. Extraction and determination of total pectic material. Analytical Chemistry, v. 24, n. 12, p. 1586, 1952. http://dx.doi.org/10.1021/ac60072a033

MELO, E. A. et al. Capacidade antioxidante de frutas. Revista Brasileira de Ciências Farmacêuticas, v. 44, n. 2, p. 193-201, 2008. http://dx.doi.org/10.1590/S1516-93322008000200005

MOURA, M. L. et al. Fruit growth and development in tomato cV Santa Clara and its "mutant" Firme. Ciência e Agrotecnologia, v. 28 , n. 6, p. 1284-1290, 2004. http://dx.doi.org/10.1590/S141370542004000600009

MYERS, N. et al. Biodiversity hotspots for conservation priorities. Nature, v. 403, p. 853-858, 2000. PMid:10706275. http://dx.doi. org/10.1038/35002501

NAGATA, M.; YAMASHITA, I. Simple method for simultaneous determination of chlorophyll and carotenoids in tomato fruit. Nippon Shokuhin Kogyo Gakkaishi, v. 39, n. 10, p. 925-928, 1992. http://dx.doi.org/10.3136/nskkk1962.39.925

NELSON, N. A. A photometric adaptation of Somogyi method for the determination of glucose. Journal Biological Chemistry, p. 135-375, 1944.

PIO, R. et al. Physical-Chemical characterization of surinam cherry fruits according to the disposition and height in the plant. Revista brasileira de Agrociência, v. 11, n. 1, p. 105-107, 2005.
RIZZOLO, A.; POLESELLO, A.; POLESELLO, S. Use of headspace capillary GC to study the development of volatile compounds in fresh fruits. Journal of High Resolution Chromatography, v. 15, p. 472-477, 1992.

RODRIGUES, L. J. et al. Caracterização do desenvolvimento de pequi (Caryocar brasiliense) temporão do sul de Minas Gerais. Pesquisa Agropecuária Tropical, v. 39, p. 260-265, 2009.

RODRÍGUEZ-FÉLIX, A.; FORTIZ HERNÁNDEZ, J.; VILLEGAS OCHOA, M. A. Cambios en enzimas pectolíticas durante la maduración del durazno 'Flordaprince'. Interciência, v. 36, 2011. Disponível em: <http://redalyc.uaemex.mx/src/inicio/ArtPdfRed. jsp?iCve=33917727010>. Acesso em: 9 nov. 2011.

ROESLER, R. et al. Antioxidante de frutas do cerrado. Ciência e Tecnologia de Alimentos, v. 27, n. 1, p. 53-60, 2007. http://dx.doi. org/10.1590/S0101-20612007000100010

RUFINO, M. S. M. et al. Metodologia científica: determinação da atividade antioxidante total em frutas pela captura do radical livre DPPH. Fortaleza: Embrapa, 2007. (Comunicado técnico).

SILVA, E. P. et al. Physical, chemicaland physiological characterization of gabiroba fruit. (Campomanesia pubescens) during its development. Ciência e Tecnologia de Alimentos, v. 29, n. 4, p. 803809, 2009. http://dx.doi.org/10.1590/S0101-20612009000400016

SILVA, L. et al. Biciclogermacreno, resveratrol e atividade antifúngica em extratos de folhas de Cissus verticillata (L.) Nicolson \& Jarvis (Vitaceae). Brazilian Journal of Pharmacognosy, v. 17, n. 3, p. 361-367, 2007.

STROHECKER, R. L.; HENNING, H. M. Análisis de vitaminas: métodos comprobados. Madri: Paz Montalvo, 1967. 428 p.

TAIZ, L.; ZEIGER, E. Plant physiology. 3 ed. Sunderland: Sinauer Associates, 2002.

VILAS BOAS, E. V. B.; CHITARRA, A. B.; CHITARRA, M. I. F. Modificações pós-colheita de banana 'Prata' gama irradiada. Pesquisa Agropecuária Brasileira, v. 31, n. 9, p. 599-607, 1996.

VILAS BOAS, E. V. B.; KADER, A. A. Effect of atmospheric modification, 1-MCP and chemicals on quality of fresh-cut banana. Postharvest Biology and Technology, v. 39, n. 2, p. 155-162, 2006. http://dx.doi.org/10.1016/j.postharvbio.2005.09.010 